\title{
Performance of cotton production and export in the major producing countries
}

DHUMISANI MOYO, Y.C. ZALA AND R.S. PUNDIR

Received : 26.05.2017; Revised : 07.08.2017; Accepted : 21.08 .2017

\begin{abstract}
The present investigation was conducted to study the growth rates and instability indices in production, area, productivity and export of cotton, and the components of output growth in the major cotton producing countries. The study used secondary data covering a period of 29 years i.e. 1980-81 to 2009-10. The analyses were carried out country wise separately for the five specific periods viz., overall study period (1980-81 to 2009-10), pre-liberalization period (1980-81 to 1993-94), postliberalization period (1995-96 to 2009-10), pre-Bt introduction period (1995-96 to 2001-02) and post-Bt introduction period (2002-03 to 2009-10). The countries concerned in the study were China, India, USA, Pakistan, Brazil and Australia. The results of the study showed that there were variations in growth rates and instability of area, productivity, production and export during the five periods. The country-wise picture was composite. Some countries witnessed higher growth and instability while others experienced a relatively low growth and instability. The analysis of components of growth in cotton output showed that the main contribution to growth in Australia, Brazil, China and USA was predominately due to area effect. Whereas, in India and Pakistan the main contribution to cotton output growth was yield effect. Technological programmes to play a substantial role in achieving high growth rate of cotton production should be designed. Such programmes and policies should include developing new high yielding varieties and provision of irrigation facilities to cotton growing farmers. Research efforts are needed to strengthen agricultural extension and the cotton breeding programmes using new efficient technologies.
\end{abstract}

KEY WORDS : Export, Growth, Instability indices, Technology, Decomposition model

How to cite this paper : Moyo, Dhumisani, Zala, Y.C. and Pundir, R.S. (2017). Performance of cotton production and export in the major producing countries. Internat. J. Com. \& Bus. Manage, 10(2) : 89-98, DOI: 10.15740/HAS/IJCBM/10.2/89-98.

\section{MEMBERS OF THE RESEARCH FORUM}

Correspondence to:

DHUMISANI MOYO, Department of Agricultural Economics, Anand

Agricultural University, ANAND (GUJARAT) INDIA

Authors' affiliations:

Y.C. ZALA, International Agribusiness Management Institute, Anand Agricultural University, ANAND (GUJARAT) INDIA

R.S. PUNDIR, Agribusiness Economics and Policies, International Agribusiness Management Institute, Anand Agricultural University, ANAND (GUJARAT) INDIA 